San Jose State University

SJSU ScholarWorks

Master's Theses

Master's Theses and Graduate Research

Fall 2017

\title{
Youth Sport Development Pathways and Experiences of NCAA Division I Women's College Soccer Players
}

Emily Hardell

San Jose State University

Follow this and additional works at: https://scholarworks.sjsu.edu/etd_theses

\section{Recommended Citation}

Hardell, Emily, "Youth Sport Development Pathways and Experiences of NCAA Division I Women's College Soccer Players" (2017). Master's Theses. 4877.

DOI: https://doi.org/10.31979/etd.53bw-66da

https://scholarworks.sjsu.edu/etd_theses/4877

This Thesis is brought to you for free and open access by the Master's Theses and Graduate Research at SJSU ScholarWorks. It has been accepted for inclusion in Master's Theses by an authorized administrator of SJSU ScholarWorks. For more information, please contact scholarworks@sjsu.edu. 


\title{
YOUTH SPORT DEVELOPMENT PATHWAYS AND EXPERIENCES OF NCAA DIVISION I WOMEN'S COLLEGE SOCCER PLAYERS
}

\author{
A Thesis \\ Presented to \\ The Faculty of the Department of Kinesiology \\ San José State University \\ In Partial Fulfillment \\ of the Requirements for the Degree \\ Master of Arts
}

by

Emily B. Hardell

December 2017 
(c) 2017

Emily B. Hardell

ALL RIGHTS RESERVED 
The Designated Thesis Committee Approves the Thesis Titled

\section{YOUTH SPORT DEVELOPMENT PATHWAYS AND EXPERIENCES OF NCAA DIVISION I WOMEN'S COLLEGE SOCCER PLAYERS}

by

Emily B. Hardell

APPROVED FOR THE DEPARTMENT OF KINESIOLOGY

SAN JOSÉ STATE UNIVERSITY

December 2017

Jessica W. Chin, Ph.D.

Ted M. Butryn, Ph.D.

Peggy A. Plato, Ph.D.
Department of Kinesiology

Department of Kinesiology

Department of Kinesiology 


\section{ABSTRACT \\ YOUTH SPORT DEVELOPMENT PATHWAYS AND EXPERIENCES OF NCAA DIVISION I WOMEN'S COLLEGE SOCCER PLAYERS \\ by Emily B. Hardell}

As youth sport has become increasingly professionalized, many believe that the route to elite level play is through early specialization. Early specialization is a contentious issue, and many risk factors have been associated with high levels and intensities of training in youth. Youth today participate in highly competitive sport in pursuit of elite levels of play, recognition, and financial gain. Early specialization is thought to be a requirement for advancement, yet little is known about the early experiences of team sport athletes who grew up in the US. This is the story of 15 elite female athletes who "made it" to Division I soccer. The study offers us a window into the professionalized and commercialized world of youth soccer. It is a description of the childhood and adolescent journeys through sport and spans $10+$ years of development. Through its telling, we learn about the expensive pay-to-play pipeline in soccer, we hear of the differences in opportunities that exist between social classes, and we confirm theories of expertise development. We learn that whether a young athlete specializes early or chooses to play multiple sports has little relevance to her progression to Division I. Through our thematic analysis of injury, we see how young athletes routinely play through injury, hide injury from coaches, and carry injury forward into their collegiate playing careers. 


\section{ACKNOWLEDGMENTS}

The final publication of this manuscript brings with it an enormous sigh of relief. I have been working on this project for many years, from its first inception as a tiny kernel of an idea when my oldest daughter first stepped onto a soccer field, to its completion on the eve of her college graduation. Without support from my wonderful children, husband, and friends, this project would never have been completed. I am forever grateful for their understanding and support. Many talented, intelligent, and supportive women have influenced me. Their wisdom and guidance have enriched my interpretations and broadened my understanding. Their moral support, compassion, and unflagging support of my work sustained me when I wanted to quit. The young women who so willingly shared their personal life stories with me touched me deeply. It was an honor to sit, listen, and converse with each of them about their life experiences in sport. I am grateful to the coaches and their staffs who so kindly offered access to their teams and facilities. I am thankful for the financial support of the Dr. David Furst Scholarship in Sport Studies and the June McCann scholarship that enabled me to complete and present the preliminary findings from this research. And, finally, I am grateful for the flexibility, support, and patience of my advisor, Dr. Jessica Chin and committee members, Dr. Butryn and Dr. Plato, at San José State University. Lastly, I am grateful for the encouragement and moral support of Dr. Wughalter who helped me cross the finish line. Thank you. 


\section{TABLE OF CONTENTS}

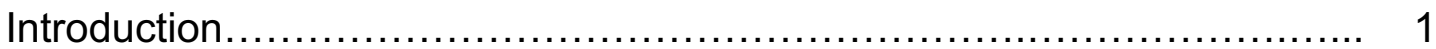

Youth Sport Participation and Trends ............................. 2

Early Specialization................................................ 6

Concerns with Early Specialization............................... 9

Diversification ..................................................... 10

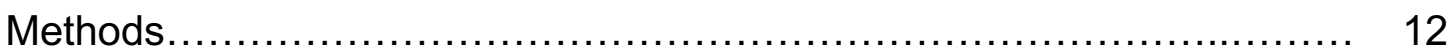

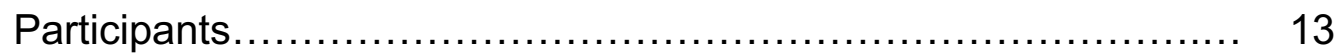

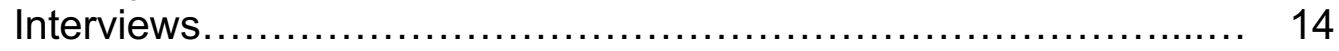

Interpretation of the Data.......................................... 15

Composite Vignettes......................................... 16

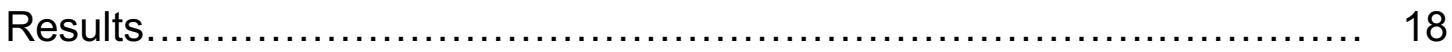

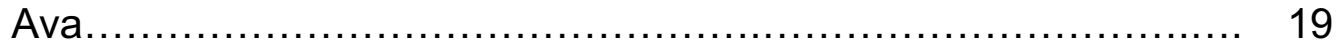

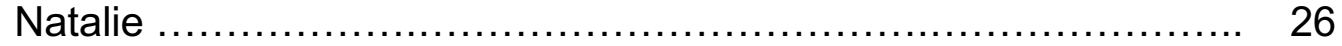

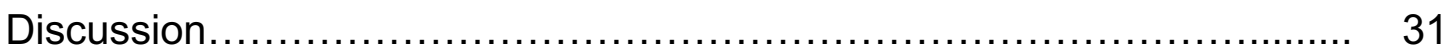

Playing Competitive Soccer................................... 32

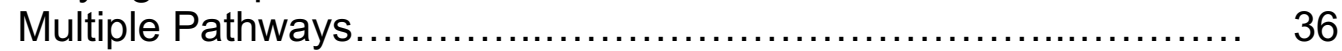

Pay-to-Play and Paid-to-Play ...................................... 38

The Injury Culture.......................................... 40

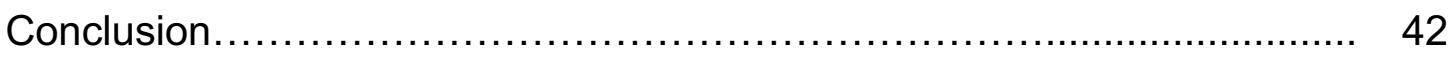

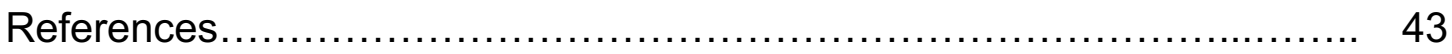

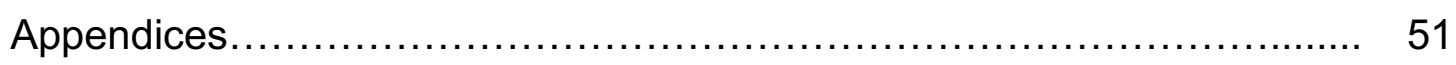

Appendix A: Participant Profiles............................... 51

Appendix B: Semi-structured Interview Guide..................... 52

Appendix C: Self-Reflexive Statement.......................... 53

Appendix D: Common Pathways................................. 55

Appendix E: Composite Vignette Themes and Sub Themes........ 56 


\section{Introduction}

Youth sport represents a key institution of socialization within contemporary society and plays a major role in children's health and welfare (Coakley, 2009; Côté \& Hay, 2002; Eckstein, 2017; Malina \& Cumming, 2003). Individual journeys through youth sport are contextual, dynamic, non-linear experiences that span childhood and adolescence. Within youth sport, early single sport specialization is a growing trend and a contentious issue (Baker, Cobley, FraserThomas, 2009; Brylinski, 2010; Gould, 2009; Strachan, Côté, \& Deakin, 2009, Wiersma, 2000). As public financing for sport has declined, youth sports have become increasingly commercialized as organizations need to generate profits to grow and expand (Coakley, 2010; Eckstein, 2017; Fawver \& Spengler, 2014; Gould, 2009). City and non-profit leagues are frequently underfunded and understaffed, and alternative options such as private sport clubs are out of reach for many middle-to-lower income children (Fawver \& Spengler, 2014).

Some parents, athletes, and coaches believe that the route to elite levels of play is through early single sport specialization, and will go to great lengths to secure athletic futures and careers for their children (Malina, 2010). Pressure to specialize early comes from coaches as they convince young athletes and parents that early specialization and intensive training is the only route to advance to higher levels of play and obtain collegiate scholarships. Specialization in a single sport during adolescence has become commonplace in today's society (Jayanthi et al., 2013; Weirsma, 2000). 
Interest in the cultivation of expert performance has a long history, and scholars have identified many biological, psychological, and social factors that may influence an athlete's participation and progression in sport (Bailey et al., 2010; Baker \& Horton, 2004; Baker, Horton, Robertson-Wilson, \& Wall, 2003; Côté, Baker, \& Abernathy, 2007). Most existing models of development lack an appreciation of the additional factors beyond skill acquisition that significantly influence participation and development (Bailey et al., 2010; Baker \& Horton, 2004). Because researchers have highlighted the importance of many social and environmental factors such as family, parents, siblings, coaches, gender, and ethnicity on young athletes' development, a consideration of these factors was warranted (Bailey et al., 2010; Baker \& Horton, 2004; Brustad, 2003; Coakley, 2009; Côté et al., 2007; Weiss, 2003). Little research has focused on the athletic development processes of female athletes (Burton, VanHeest, Rallis, \& Reis, 2006). To address this gap in the literature, the purpose of this investigation was to examine and describe the youth sport experiences and development pathways of female athletes who progressed to play NCAA Division I women's college soccer in the US.

\section{Youth Sport Participation and Trends}

Today approximately 60.3 million youngsters 6 to 18 years-of-age participate in organized youth sports and 7.9 million participate in high school sports (National Council of Youth Sports, 2008; National Federation of State High School Associations, 2016). More children than ever before in American history 
now participate in school, after school, playground, community-based leagues, travel teams, YMCAs and YWCAs, commercial facilities, and church-based programs (Sabo and Veliz, 2008). Social reasons are frequently cited for youth participation during childhood and adolescence (Côté \& Hay, 2002; Malina \& Cumming, 2003; Wiersma, 2000). The top three reasons why children and adolescents participate are to have fun, to improve, and to learn new skills (Malina \& Cumming, 2003). Most experts agree that when done correctly, participation in youth sport improves physical fitness and provides positive learning experiences (Coakley, 2009; Côté \& Hay, 2002; Malina \& Cumming, 2003).

Over the last 30 years, the trend within youth sport has been toward early specialization and competitive success (Coakley, 2009; Fraser-Thomas \& Côté, 2006; Hecimovich, 2004; Hedstrom \& Gould, 2004; Malina, 2010; Wiersma, 2000). Competitive seasons across all levels of play now last longer and may span the entire year. The multi-sport athlete is becoming a thing of the past. The prevailing wisdom indicates that if children do not specialize by the time they are in the eighth grade they will not make the cut at the next level of play (Johnson, 2008).

Historical trends indicate that youth sport has become commercialized, commodified, and corporatized, characterized by elitism, early selection, and early specialization (Eckstein, 2017; Fraser-Thomas, Côté, \& Deakin, 2008a). Many organized programs require children to focus on just one sport at a young 
age and to play year-round. The environment that young athletes train in today includes high volumes of intense training and competition, and an adult-driven emphasis on long-term success (Coakley, 2009; Fraser-Thomas et al., 2005; Malina, 2010). Many children begin early training with encouragement from their parents in the hope of securing recognition, higher levels of play, and financial rewards from their achievements (Eckstein, 2017; Gould, 2009; Malina, 2010; Pennington, 2008; Wiersma, 2000).

As youth sport has become increasingly professionalized and commercialized, questions have been raised about whether today's youth sport organizations are truly benefiting young athletes and promoting positive development (Coakley 2010, Fraser-Thomas, Côté, \& Deakin, 2005; Gould, 2009). Scholars have indicated that the benefits of organized sport programs are limited due to the loss of a child-centered focus, the lack of evaluation and training of coaches, and the unrealistic expectations of overzealous parents (Coakley, 2009; Fraser-Thomas et al., 2005; Gould \& Carson, 2004).

Physical activity and sport provide the critical foundation that enable young girls to lead strong, healthy, and fulfilled lives (Staurowsky et al., 2015). Sport researchers have described how opportunities for participation and progression differ across race, ethnicity, and gender, and have indicated that research on the unique developmental experiences of female athletes is lacking (Burton et al., 2006; Sabo \& Veliz, 2012; Sagas \& Cunningham, 2014; Staurowsky et al., 2015). Gender is identified as a key variable that contributes to different developmental 
experiences and participation opportunities (National Physical Activity Plan Alliance, 2014; Sabo \& Veliz, 2012). Youth sports offer opportunities to challenge beliefs of children and families as they relate to gender, power, and leadership (Leberman \& LaVoi, 2011). In the US, more female athletes are competing across all levels of sport than in any other time in history, and the popularity of women's sport is on the rise (Acosta \& Carpenter, 2014; Leberman \& LaVoi, 2011). While participation opportunities have increased for girls over the last 20 years, athletic opportunities remain far behind those for boys (Sabo \& Veliz, 2012; Staurowsky et al., 2015). Because youth sport organizations do not receive support from the federal government, they are not bound by gender equity legislation that requires equal opportunities for female athletes. Concerns have been raised about the pace and extent of future increases in female participation in sport (Coakley, 2009; Staurowsky et al., 2015).

Economic disparities and family characteristics drive the gender gap in athletic participation for women (Sabo \& Veliz, 2008, 2012; Sagas \& Cunningham, 2014; Staurowsky et al., 2015). Research indicates that it takes significant time, access, and money to develop and progress through youth sport in the US (Pennington, 2008; Sagas \& Cummingham, 2014). Children who have the financial resources to participate are much more likely to play and benefit from youth sport (Sabo \& Veliz, 2008; Sagas \& Cunningham, 2014). Research on youth sport and physical activity participation indicates that disparities exist 
across race and limit opportunities for millions of American children in lowincome families (Sagas \& Cunningham, 2014; Staurowsky et al., 2015).

The financial burden to families for participation in elite sports can be substantial (Coakley, 2009; Pennington, 2008; Sagas \& Cunningham, 2014). While various sources of funding exist for youth sport today, including state and city funds, grants and subsidies, corporate sponsorships, and crowd funding, parents are the primary, consistent source (Fawver \& Spengler, 2014). With the decrease in public funds for youth activity programs, sports have become increasingly commercialized as private clubs and organizations seek to generate revenue to grow and expand. It is not unusual to see company logos splashed across team web pages and even superimposed on children's photos as organizations look for alternative ways to raise money to continue operations. Offering youth sport scholarships is seen as a way of leveling the playing field for children from lower socio-economic backgrounds who cannot afford the full cost to play.

\section{Early Specialization}

Early specialization in sport has been a point of contention within research, medicine, and the public for a number of years (Baker et al., 2009; Farrey, 2008; Jayanthi, Pinkham, Dugas, Patrick, \& LaBella, 2013; O'Sullivan, 2014). The roots of early specialization are grounded in theories of how expertise is achieved, and development frameworks are concerned with the activities experienced, pathways followed, and obstacles overcome during participant development. The 
10,000 -hour or 10-year rule is frequently referred to in research and is associated with some of the myths pervasive within youth sport (Gould \& Carson, 2004). Some parents and coaches believe that an earlier start in sport will enable a child to hit the 10,000 -hour threshold of sport-specific practice sooner and, thus, get ahead of the competition. Baker and Côté (2003) suggest that the 10-year rule presented by Chase and Simon (1973) remains a good rule of thumb as it applies to the minimum level of sport-specific practice for the development of expertise in team sport.

Many theories and models of sport participation and development have been presented to explain how expertise is developed. The development of expertise in team sports differs from individual sports, and requires a mastery of a wide range of skills including individual, physical, technical, and team specific (Baker et al., 2003). Côté and colleagues described two pathways in the Development Model of Sport Participation (DMSP) that align with an early specialization or diversification approach to youth sport that lead to elite performance outcomes (Côté et al., 2007). Only a few studies have examined youth development using the DMSP as a guiding framework (Baker, Côté, \& Abernathy, 2003; Baker, Côté, \& Deakin, 2005; Bridge \& Toms, 2013; Ford, Ward, Hodges, \& Williams, 2009; Soberlak \& Côté, 2003; Strachan et al., 2009).

While no singular definition exists to describe early specialization, it is thought to include four specific parameters, including an early start age, early involvement in one sport, high intensity training, and early involvement in 
competitive sport (Baker et al., 2009). The primary benefit of early specialization is the early acquisition and development of motor skills through deliberate practice activities that require high levels of effort and concentration (Ericsson, Krampe, \& Tesch-Römer, 1993). Significant empirical evidence links the quantity of deliberate training and practice with learning and expert skill development (Côté et al., 2007). The early specialization philosophy is founded on the belief that more playing time, practice, conditioning, and coaching will lead to greater expertise in a single sport (White \& Oatman, 2009). The requirement for early specialization has been primarily supported with research on athletes playing individual sports where the age of peak performance is low (e.g., women's gymnastics, figure skating) (Law, Côté, \& Ericsson, 2008). Few studies have examined the development pathways of athletes playing team sports where the age of peak performance is reached after maturation (Bailey et al., 2010; Côté et al., 2007; Jayanthi et al., 2013).

Early specialization in one sport is based on the assumption that early specialization and deliberate practice are superior to deliberate play and involvement in multiple sporting activities. While the relationship between time spent in practice and level of achievement is well established, the requirement for intense practice and a single sport focus during childhood is not (Baker, 2009; Jayanthi et al., 2013). Difficulties have been encountered in defining and quantifying deliberate practice activities and other non-practice activities such as play and competition. Differences in methodologies exist across the literature 
related to accumulated hours of training during development and whether the quantity and quality of training may distinguish elite athletes from non-elite athletes. Additional limitations exist in the available data based on the subset of sports, sample sizes, and retrospective research designs (Baker et al. 2003; Jayanathi et al., 2013).

\section{Concerns with Early Specialization}

While many desired social outcomes are associated with youth sport participation, researchers have raised concern about early single sport specialization (Baker, 2003; Baker et al., 2009; Coakley, 2010; Fraser-Thomas \& Côté, 2006; Hedstrom \& Gould, 2004; Gould \& Carson, 2004; Gould \& Dieffenbach, 2003; Jayanthi et al., 2013; Malina, 2010). Malina (2010) highlighted the risks associated with early specialization including, social isolation, overdependence, burnout, manipulation, and injury. Additional risk factors have been identified and are thought to be associated with increased volumes of high intensity training and competition for youth including the increased risk of injury, overtraining, burnout, and dropout (Brenner, 2007; Butcher, Lindner, \& Johns, 2002; Coakley, 1992; Colvin \& Lynn, 2010; DiFiori et al., 2014; Fraser-Thomas et al., 2008a, 2008b; Hecimovich, 2004; Jayanthi \& Dugas, 2017; Johnson, 2008; Maffulli, Baxter-Jones, \& Grieve, 2005; Maffulli \& Burns, 2000; O'Kane et al., 2014; Silvers \& Mandelbaum, 2007). While injuries are an inevitable consequence of increasing participation rates, they can potentially offset the desired health benefits of sport and may lead to future 
disability and inactivity into adulthood (Anderson, 2003; Steffen \& Engebretsen, 2010). Injury in female athletes is a growing concern and has captured the attention of the medical community and the public (Elliot, Goldberg, \& Kuehl 2010; Jayanthi \& Dugas, 2017; Sokolove, 2008). Emerging evidence has begun to associate the degree of sport specialization with an increase in acute and overuse injuries in young, adolescent, female athletes (Jayanthi \& Dugas, 2017).

\section{Diversification}

The concept of diversification has been proposed as an alternative approach to early specialization and is described as participation in a variety of sports and activities through which an athlete develops multilateral physical, social, and psychological skills (Wiersma, 2000). Scholars suggest that playing multiple sports during childhood and investing in a single sport later during adolescence may yield healthier, more enjoyable, elite performance outcomes (Côté et al., 2007).

Two key elements describe diversification including involvement in various sports and participation in deliberate play (Côté, Lidor, \& Hackfort, 2009). Sampling various sports and deliberate play are thought to be essential components that enable self-regulated investment in elite sport during adolescence and adulthood (Côté et al., 2007). The theory of deliberate play is based on the premise that young athletes learn through sport activities that are fun, intrinsically motivating, provide immediate gratification, and maximize enjoyment (Côté et al., 2007). The activities are not specifically designed to 
improve performance, but offer athletes the opportunity to experiment with different movements and tactics, and the freedom to innovate, improvise, and respond strategically. Sampling various sports and deliberate play are thought to be essential components that enable self-regulated investment in elite sport during adolescence and adulthood.

In sports where the age of peak performance is reached after maturation (i.e., football, basketball, and soccer), research suggests that careers might be longer for athletes who follow a more diversified pathway (Côté et al., 2009). Few studies have examined the concepts of diversification and deliberate play for the development of elite performance in team sports where the age of peak performance is reached after maturation (Baker et al., 2003; Baker et al., 2005; Bridge \& Toms, 2013; Leite, Baker, \& Sampaio, 2009; Soberlak \& Côté, 2003).

Despite concerns raised related to early specialization in sport, many children begin specialized training at young ages with encouragement from their parents in the hope of securing elite levels of play, recognition, and financial rewards for their achievements (Jayanthi et al., 2013; Malina, 2010). The purpose of the current project was to investigate female athlete development through sport from the vantage point of those who "made it" and learn from their success. A primary aim of the study was to trace the developmental trajectory of athletes from their earliest memory of playing soccer to the time they were accepted on a Division I women's college soccer team. In so doing, theories of early specialization and diversification were investigated, and the findings contribute to the literature for 
athletes playing team sports where the age of peak performance is after maturity. A discussion of the factors that athletes identified as influential to their journeys broadens our understanding of the complex variables that influence the decision to specialize or follow a more diversified pathway through youth sport in route to elite levels of play.

\section{Methods}

Many methods have been used to examine the activities experienced, the pathways followed, and the obstacles encountered in route to elite level sport performance (Bailey et al., 2010). A qualitative research design was chosen because little is known about the early experiences of female athletes and the factors that influence their progression to elite level sport within the US. Evolution of the design and flexibility in the research process were important criteria to ensure that the unique experiences of the athletes (i.e., thoughts, feelings, beliefs, and assumptions) could be captured (Denzin \& Lincoln, 2003;

Marshall \& Rossman, 2006). Throughout this process, the researcher was able to draw upon the existing literature to further examine the subjective views of the participants (Hesse-Biber \& Leavy, 2011). The study design enabled the researcher to further explore emergent areas of interest and draw out the factors that had a significant impact on athletes' experiences and development within the youth soccer system. 


\section{Participants}

Following Institutional Review Board approval, 15 student-athletes who were eligible to play NCAA Division I women's college soccer were recruited from two institutions in Northern California during the 2015-16 academic year (see Appendix A). The study was delimited to female student-athletes because gender differences have been associated with access and participation opportunities in sport within the US, and research on elite female development in sport is lacking (NPAP, 2014; Sabo \& Veliz, 2012; Staurowsky et al., 2009).

Eleven of 15 student-athletes who participated in this study received a scholarship to play Division I soccer. Participants ranged in age from 18 to 21 years and were available in the first half of 2016. The profiles of the two schools selected were purposely very different as team rankings are an important factor in the college recruiting process in soccer. One of the schools chosen was a small private university, the other a large public university. Within the NCAA Division I rankings for 2015, there were over 300 Division I women's soccer programs located across the US. The two schools chosen for this research ranked in the top one-third, and middle one-third, respectively. The primary researcher conducted one-on-one, in-person interviews with all volunteers who were available in the first half of 2016 . Self-reported categories of ethnicity included: White/Caucasian (9), Asian/Caucasian (1), Mexican/American (1), Mexican/African American (1), Mexican/Filipino (1), African/American (1), Mexican/Hawaiian/Caucasian (1). 


\section{Interviews}

Developing trust, rapport, and relationship with participants is an important part of the research process (Dale, 2000). One-on-one, in-person, retrospective interviews were conducted, and a semi-standardized interview procedure was followed (Berg, 2004). Consistent with previous research methods, retrospective interviews were used to gather information related to the development of expert performance in sport (Côté, Ericsson, \& Law, 2005). A copy of the consent form and interview guide (see Appendix B) were distributed to each participant approximately 1 week prior to the scheduled interview date. Quiet, convenient locations were selected by the participants for face-to-face interviews. The choice of interview location was important as it enabled the athletes to expand upon emotionally sensitive topics without distraction or loss of confidentiality.

The overall objective of the interview was to shift the balance of power to the athlete and encourage a monologue discourse on the research topic (Berg, 2004). This approach allowed the athletes to further expand upon the interview

questions and contribute additional historical information that described the social environments where they grew up.

Each interview began with a series of short, easy-to-answer questions including age, demographic information, where the athletes grew up, and an early memory of their first experience with soccer. The initial interview guide was modified as the interview process unfolded. As the interview progressed, the researcher disclosed personal information to build a sense of trust and rapport 
with each participant. An open-ended question was included at the end of each interview to allow participants an opportunity to add any additional information they felt was relevant to the research topic. Participants provided rich, elaborate, and sometimes emotional descriptions of their experiences, and all interviews lasted at least 60 minutes. Many of the athletes expressed excitement and gratitude to have been able to participate in the research project.

\section{Interpretation of the Data}

Prior to data collection, the primary researcher participated in an in-depth, reflexive interview conducted with an expert in qualitative research (Yungblut, Schinke, \& McGannon, 2011) (see Appendix C). The primary researcher transcribed all interviews and conducted an inductive thematic analysis following the procedures outlined by Côté, Salmela, Baria, and Russell (1993). Member checking of transcripts was performed to enhance the academic rigor of the study, and all participants were offered an opportunity to review their transcript and provide additional input or remove any words from their interview (Lincoln \& Guba, 2006; Miyata \& Kai, 2009). As part of the data analysis process, a visual representation of the individual development pathway for each athlete was created to highlight key events, activities, and patterns across the data (see Appendix D). The primary researcher kept a detailed audit trail and a journal of all working assumptions, interpretations, and reflections throughout the research process (Lincoln \& Guba, 2006; Miyata \& Kai, 2009). Regular progress reports 
and data review sessions were conducted with an academic advisor trained in qualitative research methods.

\section{Composite Vignettes}

The results of this project are presented using two composite vignettes entitled "Ava" and "Natalie." The composite vignettes were constructed from the data for each major theme (see Appendix E) and were designed to present the stories of athletes from different socio-cultural backgrounds and highlight the influential factors that emerged across the different development pathways during childhood and adolescence. The primary researcher felt that using composite vignettes to present the results would complement the research process and be an effective way to blend the voices of multiple athletes as well as highlight the major themes that emerged during the inductive thematic analysis. By consolidating and presenting the themes using vignettes, the intent was to make the research more accessible to a wider audience and offer a more intimate descriptive account of the individual and collective experiences of 15 elite athletes who participated in this study (Spalding \& Phillips, 2007).

Vignettes have been used within research for more than 25 years and recently have been used to highlight particular findings, summarize themes, and centralize participant voices within qualitative research (Burton et al., 2006; Spalding \& Phillips, 2007; Yungblut et al., 2011). The methods used in this research are similar to those used by Burton et al. (2006) in their study of US female Olympians, and Yungblut et al. (2011) in their study of female adolescent 
views on physical activity. The use of composite vignettes also draws upon the insights provided by a fellow novice researcher of her experience using vignettes in an action research case study (Spalding and Phillips, 2007).

Similar to the approach used by Burton et al. (2006), two composite vignettes were created and presented as athlete stories. They contain a mix of direct quotes and narrative that best encapsulate parts of the common athlete experience. The quotes that are presented in the vignettes are the exact words used by one or multiple athletes as transcribed from taped interviews. Similar to the method used by Yungblut et al. (2011), each composite vignette is comprised of direct quotes and narrative incorporating the language and words used by the athletes to offer the reader a greater depth of insight into the athletes' experiences and to increase the trustworthiness of the study (Yungblut et al., 2012).

One of the biggest challenges during the vignette creation process was deciding which themes to present in the results. After multiple iterations and reviews with an expert panel, the final themes were narrowed down and two vignettes were created from the thematic data. The final themes chosen for inclusion were highlighted as influential to the athlete's development in soccer and selected based on their expected level of new contribution to the literature. By joining together 15 strong young female athletic voices and sharing their experiences through the use of composite vignettes, the findings serve to 
increase our understanding of young athletes' journeys through sport in route to elite level performance in soccer.

\section{Results}

During the analysis process, the primary researcher identified two different pathways that align closely with the DMSP (Côté et al., 2007). Two major themes were identified that significantly influenced athletes' progression through the youth soccer system: starting early and playing competitive soccer. The culture of injury was explored and four unique sub themes were identified including played through injury, hid injury, accepted injury, and carried injury forward.

During the data interpretation process, athletes were identified as having followed either an early specialization pathway or a diversification pathway through youth sport consistent with the descriptions offered in the literature (Baker et al., 2009; Côté et al., 2007). The sub themes for these athletes were then grouped together for presentation using two composite vignettes entitled Ava and Natalie (see Appendix E). The primary findings that differentiated the early specialization pathway from the diversification pathway centered around the amount of exposure athletes had to other sports during early development and the age when they made the decision to give up participation in other sports to focus on soccer. The composite vignettes illustrate the presence of these themes in the athletes' narratives. Athletes who followed an early specialization pathway had minimal exposure to other sports between the ages of 3 and 9 , and made a much earlier commitment to play competitive soccer exclusively between the 
ages of 6 and 10. Ava's story reflects the common themes of athletes who followed an early specialization pathway through youth sport.

\section{Ava}

Ava dreamed of becoming the "face of women's soccer" and was actively planning a career in professional women's soccer after college. Her earliest memory of playing soccer came when she was 3 years old. She remembers kicking a miniature ball against the wall in her apartment, watching soccer videos, and playing soccer with her parents. She remembers being worried about putting a hole in the wall if she kicked the ball too hard.

I think my earliest memory is just of playing with a little soccer ball, like a miniature soccer ball, in my apartment with my parents...So I lived in like a sketchy neighborhood, and so I really couldn't go outside a lot. And so right when I started walking, like maybe around three, I would just pick up a soccer ball and kick it against the wall...So I remember him [father] buying like tutorial videos, like how to do moves, and I would do them inside my apartment, inside this tiny hallway, practicing these moves all day with the ball. Yeah, so that was before I was getting out on the field and stuff with the ball.

At the time of the interview, Ava was 19 years old. She was the third child in her family and grew up in a single parent household. Ava had two sisters, one older brother, and was an athlete of color. Her parents divorced at an early age, and she spent the majority of her childhood and adolescence with her father.

From an early age, Ava and her siblings played soccer at a park across the street from their home because it offered an escape from difficult times at home. Ava's siblings all tried soccer during childhood and her brother continued to play for many years. Ava's father grew up playing soccer in Mexico during his youth and 
was very involved throughout her youth soccer career. Ava came from a "soccer family":

... because we were such a huge soccer family and we watched a lot of soccer. And with my dad we would just play games and we would just TiVo them...So it was definitely all around me, soccer. ...So he [father] played a lot of soccer. And he definitely watches a lot of soccer too. And so when I was growing up he made me watch a lot of soccer too...so he [father] coached me growing up... but so he also coached my older brother...So I pretty much come from a soccer family.

Ava's father coached her soccer team for many years in addition to her brother's team. He provided transportation to and from practice, games, and tournaments until Ava was old enough to drive herself. When Ava started playing on elite level teams, her father provided additional coaching and training for her and her brother at the local track and gym. He played the role of Ava's "manager" and would frequently contact other coaches to see if Ava could guest play for teams who were competing in high level tournaments.

As a single parent with four children and two playing competitive soccer, Ava's father had difficulty juggling his work schedule and supporting his children's busy schedules. He sometimes lost his job because of conflicts with soccer, and at one point the family moved in with their grandmother so he could continue to pay for their sports.

Ava developed a very close relationship with her father through soccer and became her father's "athletic child." During high school Ava did not want to hang out with any other friends, but cherished the time she was able to spend with her father. Ava did not have much contact with her mother growing up as her soccer 
schedule prevented her from seeing her mother on many of her scheduled visiting days. Ava's relationship with her father continued to be close in college, and he frequently visited her and came to see her play. When asked about the biggest influence that enabled her to play Division I soccer, Ava credited her father. Every time Ava steps on the field she is playing for herself and her father, and hoping to make their dreams come true:

[Biggest influence?] It was probably my dad because he never really got to play at the level that he wanted to, that he worked so hard for it. And so I was like, I will play for you too. I want to make your dream come true, living through my dream, that kind of a thing.

Even though Ava tried a few other sports through a local sports camp during childhood (age 6), she identified herself as a soccer player from a very young age. Ava did not try any other organized sports until she entered middle school, and then she played volleyball and ran track for her school team. Once Ava began playing competitive soccer at age 8 her commitment to soccer became "serious":

... because I already bonded with soccer being a life decision. I knew that if I got into soccer, sometime as a child I knew it would be eat, breathe soccer. It was still fun. But as you get older it's like I need to go to the gym instead of eating a bag of chips...I did have to sacrifice a lot. Friends were easy and that was nice, but when your friends want to hang out with you, you're like sorry I can't because I have soccer. That made it more of the job aspect of it, I'm gonna put in all these hours, and hopefully it just pays off. And so I put all my eggs in that basket [soccer]... And of course, my situation I was lucky enough that it did [pay off]. But that's not always the case. I was just really really lucky.

Around age 11, Ava began playing on multiple teams simultaneously and frequently played four games in one day on a weekend. Her father would shuttle 
her to different fields to play for multiple teams on Saturday and Sunday. Ava "worked hard," trained often, and "set goals" for herself in soccer. Some of the ambitious goals Ava set for herself included playing Division I soccer, playing in the Olympics, and playing in the World Cup. Ava was required to attend annual "tryouts" to keep her roster spots each year while playing competitive soccer. She described how stressful tryouts were, and how at age 11 she had to compete against $100+$ girls for a spot on the newly formed Olympic Development Program (ODP) team for her age group. Ava ended up making the team and went on to play on various ODP teams for 7 more years. When Ava reached middle school, team "rankings," "tournament placement," "scholarships," and playing for "elite teams" became more important as she progressed through the competitive youth soccer system. Ava was frequently approached by coaches of other teams to play for them and she came to expect payoffs in the form of scholarships for her efforts. To Ava, soccer was everything. It was a "lifestyle."

Once Ava moved to competitive soccer, her family could not afford the full cost to play, and she relied upon financial assistance from her club teams to keep playing. While playing competitive soccer, other coaches would try to lure her away from her existing team and recruit her to play for their teams, with the promise of a youth sport scholarship:

As I got older, then other organizations wanted you to play for them. After select [soccer], I had a really fortunate opportunity for a club coach to want me to come play for him for no cost. He would pay for everything as long as I would play for him. So of course, then it was a financial option for us we could do that...and so then when I got a little older, my clubs, I told them, I can't 
afford to travel. ... and so then they were like okay we will give you a scholarship. So all my clubs they mostly paid for me because they knew...

Ava commuted $2 \frac{1}{2}$ hours each way to play on an Elite Clubs National League (ECNL) team during high school. She talked about how soccer and school consumed all of her time, and she didn't have much time for other high school activities or many friends. Ava played soccer on her high school team and "made varsity" her freshman year. She quit after playing for 2 years because she felt she got worse playing for her high school team. Ava described how the skill level of her high school team was so much lower than club, and the coach did not know much about soccer.

Ava incurred a number of injuries playing competitive soccer during adolescence. She sometimes hid injury from her coaches and felt pressured to play through her injuries from a young age in order to keep her roster spot and scholarship:

So, I think I was out for over 2 to $2 \frac{1}{2}$ months with that one [injury]. And so I got called to the regional team...I was supposed to travel to Florida with them. And so I didn't tell them. I didn't tell them I had a cast on...And so I think I had my cast on for two weeks, if that...And so he [father] took me to another doctor so they could take off my cast. And so he was like, it's time for her to get her cast off...And so I was running with a broken ankle. And so I had to go to Florida with a broken ankle. And so I think by then I would just tape it up and it was fine...And so it was hard. And so to this day, it still hurts sometimes, but they never knew... It was pretty crazy.

Ava sustained a number of different types of injuries while playing competitive soccer including multiple concussions, broken nose, broken toes, dislocated shoulder and elbow, a fractured foot, plantar fasciitis, strained ligaments in her knees, multiple avulsion fractures in her pelvis, stress fractures in her feet, 
sprained ankles and knees, and back injuries. Even though she described how some of these injuries kept her out of the game for periods up to 5 months, she felt lucky to have escaped more serious injury, "I have been lucky enough to not have any really bad injuries and I am very grateful for it." Ava was very aware of how a serious injury could impact her progression within competitive youth soccer and ultimately her ability to be recruited to play in college. She provided an emotional account of an injury suffered late in high school and how it impacted her final year playing club soccer with her team. After this part of the interview, the recorder was turned off so Ava could regain her composure and continue the interview:

So my last year of club was difficult, right. Because again, you lose your starting position because you're injured. Someone else had to fill in the gap. And so I never really got back to my starting position. ...During club because the person that took over my spot she was killing it. And so at the same time, I was really happy for her and I wanted what was best for the team, but it was also so stressful. Because you're going to college next year and so you signed to play Division I and so you just want to train and you feel like if you're going to be playing at that next level, like you should be playing for your club team. And yeah, so that was very difficult. Being a starter all my life, and then... then just not having that experience my last year was hard.

"Being seen by college coaches" emerged as an important component of the college recruiting process. Ava's father frequently sought out opportunities for her to play on highly ranked teams. Playing on an elite level team was necessary for Ava to increase her visibility within the recruiting process. Within youth soccer, college coaches usually only attend high level tournaments where elite level teams compete. 
Ava was recruited during her freshman year of high school. She was invited to visit a variety of big-name Division I college programs and kept in touch with many college coaches for an extended period of time. She frequently talked to coaches on the phone and kept a detailed log of all of her interactions. Ava needed a full ride scholarship to attend college, and this was a key part of her decision to accept the offer to play at her current school.

Ava had multiple offers to play Division I soccer and eventually decided to play for a coach she had played for previously on an ODP team, and who offered her a full ride scholarship:

...I committed as a freshman. So I looked at every school, and so I remember we were coming up here to visit... and so I really didn't love the school but I loved the program. And so it was a big-name school and l've always wanted to go to a big-name school and all that stuff...I need to get a full ride that's my goal. I don't want to make my parents pay....so we are sitting down and so he was like, you don't have to pay a penny. You don't have to pay anything to come here.

The minimal amount of exposure Ava had to other sports during development and the age when she gave up participation in other sports to focus on soccer differentiated Ava's pathway from Natalie's. The Natalie composite vignette illustrates how athletes who followed a diversification pathway had extensive exposure to other sports during childhood, played multiple sports during adolescence, and made a much later commitment to play competitive soccer exclusively between the ages of 14 and 15 . Natalie's story is comprised of the common themes for athletes who followed a diversification pathway through youth sport. 


\section{Natalie}

Natalie loves playing women's college soccer at her current school. She loves hanging out with her teammates and competing at the top level of her sport. She is very aware that her opportunity to play college soccer is coming to an end very soon. She is thinking about pursing an opportunity to play soccer in Europe after college so she can support herself, travel, and see new places.

Natalie's earliest memory of soccer came when she began playing recreational soccer at age 5 . She reminisced about dressing up and parading down main street and hearing parents "from both sides yelling and cheering" for her in her home town. She recalled many minute details about her first teams, including the funny team names (e.g. Pioneers, Ladybugs, Daisies, Diamonds, Panthers, and Mighty Mouse), post-game snacks, long grass, little goals, and her parents cheering her on from the sidelines. She enjoyed reflecting on the memories and talked about how her niece was currently going through the same experience right now.

Natalie grew up watching her older sisters play soccer. She played soccer with her best friends and loved how she would always score lots of goals. Always an active, competitive child, Natalie was very fast and aggressive on the soccer field. Natalie loved soccer from an early age:

[soccer]...it was just enchanting. Something new. A new experience. And you have this magical orb in front of you...It's pretty exciting to put all your energy into kicking a soccer ball...so I took to soccer, unlike other sports, and then I just really loved it. 
Natalie was the youngest child in her family and 20 years old at the time of the interview. She grew up in a two-parent family with two older sisters and described herself as white/Caucasian. Both of Natalie's sisters progressed through the youth soccer system and went on to play college soccer. Natalie's parents had a rudimentary knowledge of soccer and had played other sports during their youth. Both parents continued to play recreational sports as adults. Her father worked and her mother was the primary parent responsible for supporting the after-school activities of Natalie and her sisters.

Natalie grew up in the same house and the same neighborhood her whole life before moving away for college. She was a multi-sport athlete from an early age and came from an athletic family, "I came from a family, not a soccer family at all. We played softball, baseball, basketball...the whole family." Natalie lived very close to a large sports complex where she tried many different sports during her youth. She appreciated when her parents could come see her play as her game schedules frequently conflicted with her siblings' schedules. It meant a lot to her when her parents and or other family members could come watch her games.

During childhood, Natalie's mother encouraged her to try many different types of sports and to play for the highest-level teams that were available to her. At age 10 Natalie was encouraged by her parents and coaches to try out for a competitive soccer team. For Natalie, this was the earliest age that she could officially try out for a more competitive team within her club. Natalie was nervous trying out for her first competitive team and was very excited when she got the 
call that she made the team. Once Natalie started playing competitive soccer, soccer became "more serious" and "missing practice was a big deal." Even though she had to try out annually for team placement, it was more of a formality for returning players. New players who wished to join had to demonstrate far greater skill than existing players to earn a spot on the team.

Once she transitioned to competitive soccer, Natalie trained and competed year-round. She began traveling farther distances to play in tournaments and really enjoyed the "traveling aspect" of soccer. Natalie frequently traveled up and down California, and out of state to play in tournaments. Her team even had an opportunity to play in an international tournament: "Puma sponsored like the Sweden trip, but there is a lot of traveling. I've been to Oregon, Nevada, Arizona, North Carolina, up and down California." Natalie loved the recognition of playing on an elite level team and described a time when her team was mistaken for an Olympic team when they were waiting for a flight. Natalie enjoyed the comradery of traveling with her mother and teammates, who were also her closest friends. While Natalie's life was significantly impacted by the amount of training and competition required, she felt she could maintain a "somewhat decent social life" and participated in some outside activities away from soccer. Natalie played for the same soccer club throughout her youth soccer career and developed close family-like relationships with her teammates and coaches.

During middle school, Natalie played volleyball, basketball, and ran track for school. She would frequently miss school team practices because of conflicts 
with competitive soccer. During basketball season, she rarely made it to practice and just showed up for games. Her school coach wasn't happy about Natalie's schedule conflicts with soccer but was willing to work with her because he needed "athletic girls" on his team.

When Natalie was 13 years old, her club team became part of the ECNL and she was offered a place on the newly formed ECNL team for her age group. Natalie was able to take advantage of this opportunity because her parents could support the financial, travel, and time commitments required for her to play at this level:

So this is the point at which ECNL had just started. It was the first year of the ECNL and no one knew what the hell it was...and so all I understood from this was that we were going to be traveling a bunch of places...And so I remember my dad telling me it's going to be pretty expensive because I think it's roughly about $\$ 10,000$ a year with traveling plus the soccer expenses plus everything. It was a big commitment...

Once Natalie began playing ECNL, her focus shifted to playing in college. Natalie described how significant playing in the ECNL was to her ability to be recruited to play Division I soccer:

....and for girls there's ECNL. Have you heard about ECNL? So, it's like the national league and coaches just swarm. And so, you can get recruited even as a not very good player to somewhere nice. And so, it's just a lot easier for girls right now. ...Everyone on my team went on to play at a college. All but three went on to play at a Division I. ...I think the only reason that you would've stayed on the team was to continue to go on to the next level.... Because if not, there is another girl who would want your spot on the team. That's how intense being in the ECNL was... so you play for the ECNL to get recruited.

When Natalie entered high school, it became too difficult to juggle the demands of playing multiple sports, and she gave up her other sports to focus on 
soccer. Natalie played varsity soccer all 4 years of high school even though many of her teammates decided to forgo playing school soccer and continued training with their club teams. Natalie loved playing high school soccer:

High school [soccer], loved it. I loved it, it was so much fun. It was like practice. It was fun. It was kind of like a fun break from club soccer. And playing for your school, is just the greatest feeling...Three players that were on my club team, we each played defense, midfield, forward, so, we were all together. It was stacked. So, I don't know about the other players, but it was fun. I made varsity as a freshman. ...So, it's like I made varsity as a freshman, I get the letterman's jacket, it's so cool. ....only three of us freshmen were on varsity. So, it was a big deal.

Injury was discussed as a physically and emotionally challenging part of Natalie's journey through youth soccer during adolescence. During her sophomore year, Natalie suffered a knee injury that sidelined her for 8 weeks.

She described how painful this injury was and how it ended up being a major turning point for her in deciding to pursue a collegiate soccer career:

Well my sophomore year of high school, I had a knee injury. A pretty bad injury. An injury I never had growing up. So I slightly, it wasn't terrible, it definitely could've been worse, but I slightly tore my meniscus... And so that was the longest l've ever had to be out of sports in my entire life. And it just made me realize, like holy moly, I'm not done playing this sport. It was kind of a wake-up call for me...so that was a major turning point I think in my high school years that made me want to get here.

Natalie accepted injury as "...just part of the game," and she continued to be impacted by injuries she suffered earlier in her youth:

...so that ended up screwing me over now, that I'm older because I don't have mobility. I went to treatment after I got the cast off because they were like, you need to get your mobility back and stuff. Then I always wore a brace. And even now, I can't bend this ankle as far as I can the other one. And so, now it really hurts me. And on the field if I jump up and land on it wrong, it just stings a little bit and it's just so locked up. And sometimes in cold weather, or a lot of cutting on it or pushing off, it tends to hurt a lot more, and I 
already have arthritis in it. Yeah, I'm gonna have to get surgery when I'm done with soccer, to repair stuff in there, and I have this huge bump on it and it's so ugly.

The support of her parents was one of the biggest influences that enabled Natalie to make it to Division I. During most of Natalie's youth soccer career, her mother was a stay-at-home mom and provided countless hours of support that enabled Natalie to play and compete. Once Natalie began to play competitive soccer, her mother provided carpool support for her daughter and other teammates. Natalie's mother volunteered as team mom and frequently traveled with the team and provided supervision and support during tournaments away from home (e.g., driving the rental vans, making travel arrangements, arranging meals away from home). Natalie's mother was very supportive during times of emotional upset or set back during Natalie's playing career and was highly influential during the college recruiting process. Natalie maintained a very close relationship with her mother through soccer.

Natalie was currently living out her dream of playing Division I soccer. She received a full ride scholarship and was recruited during high school by a local coach who came to see her play at an ECNL game:

So I had the full ride... and I was like wow, they'll pay for everything. I don't have to pay for anything at all. That would be like a dream come true for my parents, for me.

\section{Discussion}

While many studies have examined a multiplicity of factors that affect participant development in sport, few studies have explored the youth sport 
development experiences of female athletes who progressed through the competitive soccer system within the US and eventually made it to play Division I women's college soccer. Many factors were highlighted that serve to confirm findings from previous research and add to concerns related to the institutionalization, professionalization, and privatization of youth sport in the US. The discussion focuses on the factors that were identified as influential to athletes' development in soccer and that add new insight or subtle nuances to the available literature on athlete development pathways and experiences in youth sport.

\section{Playing Competitive Soccer}

Playing competitive soccer emerged as the most significant factor that influenced athlete development and progression to Division I soccer. The players uniformly underscored the importance of starting to play soccer at a young age (ages 4 to 6), committing early to play competitive soccer (by age 10), playing for highly ranked national teams, and playing for the ECNL.

The description of the environment where Natalie and Ava played recreational soccer differed significantly from competitive soccer. Natalie and Ava fondly reminisced about playing recreational soccer during early childhood and seemed very relaxed and almost wistful as they recounted their earliest memories. They used words such as "new," "enchanting," "super fun," "good time," "exciting," and "love" to describe this early period in their lives, and it was clear that they developed an early love and passion for the sport while playing recreational 
soccer. These findings are consistent with previous literature that describe fun and doing something the child is good at as two fundamental reasons why children participate in sport (Malina \& Cumming, 2003).

As soccer has grown and become increasingly popular within the US, it may be the first sport that a child is introduced to and, thus, is in a unique position to keep youth playing soccer exclusively throughout childhood and adolescence. Natalie and Ava described how they were early standouts in recreational soccer and were quickly moved onto more competitive teams. While playing recreational soccer, Natalie and Ava described themselves as "competitive," "good at soccer," "aggressive," "strong," "dominating," and "fast." They developed skills quickly, "scored lots of goals," and stood out from their peers. Their early visible skills contributed to their being selected by coaches to "move up" to more competitive teams. When these athletes played youth soccer, the earliest age they could play competitive soccer was 10 . Since that time, changes in the soccer system have enabled children to begin competitive level play by age 8 . These early selection and talent identification processes illustrate how children are initially identified, selected, and then encouraged to move to more competitive levels of play at young ages. Once athletes are in the competitive system, the time and resource expectations rise and athletes must make greater commitments to their sport in order to keep their roster spots, or earn places on more selective level teams. 
Once athletes committed to higher levels of play, the time commitment for practice and competition ramped up each year. During middle school, the soccer season became year round as athletes practiced and competed throughout the school year and then over the summer. Most holidays were spent traveling with family and friends for soccer, and athletes began to travel farther distances from their homes to compete. As competitive soccer begins at younger ages (age 8) and the volume of play increases annually, the ability of a young athlete to sample other sports declines. The inherent year-round structure and volume of play required to stay within competitive soccer are two factors that contribute to early specialization in youth.

Once athletes began high school, they dropped all other sports because they were unable to juggle the demands of playing multiple sports. During high school, competitive soccer schedules spanned the entire year and athletes had "no breaks." The American Medical Society for Sport Medicine recommends placing limits on yearly sport participation time, particularly during the adolescent growth spurt (DiFiori et al., 2014). In addition, pediatric medical guidelines recommend that young athletes take scheduled breaks every 2 to 3 months to focus on other activities and cross train to prevent loss of skill, allow for recovery, and prevent injury (American Academy of Pediatrics, 2000). With the current structure of the high school and competitive soccer seasons, this is virtually impossible. Today, young female athletes finish their rigorous fall competitive schedules and then head right into their high school season. Once the high 
school season ends, club begins again in the spring. During the high school years, there is no down time from soccer unless the athlete chooses to skip playing high school or sits out a season of club. These findings contribute to concerns regarding the volume of play associated with competitive youth sport, and demonstrate how the current structure and schedule of competitive and school sports may be contributing factors that prevent young athletes and families from following recommended guidelines for annualized rest and recovery periods.

Researchers have described how the desire for elite team selection and collegiate scholarships are driving the early start age in competitive youth sport (Malina, 2010; Pennington, 2008). The importance of playing for a highly ranked team emerged as a significant factor that had implications to athletes' progression in soccer. As youth soccer in the US has expanded, the number of leagues offering national level competition has grown. Natalie and Ava both had the opportunity to play on elite teams, including highly ranked club, ODP, national, and ECNL teams. Many athletes like Natalie played on at least one elite level team. Others like Ava played on multiple elite teams, sometimes at the same time. Playing for highly ranked elite level teams emerged as an important criterion for young athletes who wanted to play college soccer.

In 2009, the ECNL was formed and has transformed the college recruiting process in women's soccer. Evidence of the impact of the ECNL league was seen throughout discussions of the college recruiting process. Athletes 
described how "coaches swarmed" to ECNL events, and how one could get recruited even "as a not very good player." Athletes playing for ECNL teams had significant advantages over athletes who did not. Natalie discussed how her club team was converted into an ECNL team. She went on to describe how playing ECNL offered her tremendous visibility to college coaches and enabled her to get multiple offers to play in college. Playing for an ECNL team emerged as a significant advantage for athletes during recruiting, and was seen as a ticket to play Division I soccer. This finding, coupled with the irrelevance of playing high school soccer in the recruiting process, demonstrates the importance of playing competitive soccer for young athletes who desire to play in college. It also highlights how playing competitive soccer advantages those who can afford to play, and disadvantages those who cannot. These results add to the existing literature that describes how pay-to-play organized youth sport has become increasingly institutionalized with an emphasis on competitive success and elite performance outcomes for the talented few who can afford to play (Coakley, 2009; Fraser-Thomas et al., 2005; Fraser-Thomas et al., 2008a; Gould, 2009; Malina, 2010).

\section{Multiple Pathways}

Theories of deliberate practice and play were explored during this investigation. The Development Model of Sport Participation (DMSP) (Côté et al., 2007) was used as a general model to understand the stages of development in sport, and to further examine the concepts of specialization and diversification. 
While some athletes followed an early specialization pathway to reach Division I, others chose to play multiple sports for many years. Whether an athlete played a single sport or multiple sports during childhood did not seem to have much relevance to their eventual progression to Division I.

The primary characteristic that differentiated an early specialization pathway from a diversification pathway was the age at which athletes gave up other sports to increase their commitment and focus on soccer. Athletes like Ava, who specialized early, typically made a greater investment in soccer between the ages of 8 and 10. Athletes like Natalie, who followed a diversification pathway, made a greater commitment to soccer typically between the ages of 14 and 15 . The evidence of both early specialization and diversification pathways leading to Division I soccer is consistent with the DMSP that describes multiple pathways for the development of expert performance outcomes (Côté et al., 2007).

A significant finding from this research is that whether an athlete followed an early specialization or diversification pathway through sport had little relevance to their eventual progression to Division I soccer. The results indicated that all athletes started playing competitive soccer at a young age and played for more than 10 years, regardless of whether they chose to play one sport or multiple sports during childhood and early adolescence. These findings provide additional support for previous research that describes the positive relationship between time spent in deliberate practice and the premise that it takes 10 years to reach 
expert status in sport (Baker et al., 2003; Ericsson et al., 1993; Helsen, Starkes, \& Hodges, 1998; Law, Côté, \& Ericsson, 2008).

\section{Pay-to-Play and Paid-to-Play}

Playing competitive soccer is expensive and was found to be cost prohibitive for some families. These two findings are consistent with previous literature and illustrate how the cost to play competitive soccer has risen out of reach for many families from lower socio-economic backgrounds (Coakley, 2010; Fawver \& Spengler, 2014). A new finding illustrated how athletes who could not afford the full cost to play were reliant upon youth sport scholarships throughout their early playing careers.

Ava's family was dependent upon a financial scholarship to play throughout her youth career. Receiving a youth sport scholarship was an important factor that enabled Ava's progression pathway through the youth soccer system and her eventual recruitment to play Division I soccer. In contrast to Ava's story, another athlete, "Emma," was prevented from playing competitive soccer because her family could not afford the cost of play. Like Ava, Emma had an early tryout for an elite level club team, made the team, and then could not come up with the fees to accept the spot on the team. Even though Emma was a "naturally talented" athlete, she did not have the opportunity to participate in many organized sports because of the time and money required. Emma was not offered a youth sport scholarship to play competitively and continued to play soccer in a "Sunday league" throughout childhood and adolescence. Her 
opportunity to play Division I soccer came through a "random encounter" with a community college coach who saw her play during a high school game. After playing at a community college for 2 years, Emma transferred to a Division I school and received a scholarship to play. These findings suggested that young talented athletes who cannot afford the cost to play competitive soccer and who do not receive financial assistance are very unlikely to make it to Division I programs.

Receiving a youth sport scholarship added additional pressure on young athletes to perform, and scholarship recipients felt like they were "paid-to-play" from very young ages. While the availability of a youth sport scholarship enabled Ava to continue playing competitive soccer, it also served as a powerful incentive to move to more elite level teams. As time passed, Ava felt like she was "paid-toplay" and felt increasing pressure to perform well and play through injury from a young age. These findings add to concerns related to the potential physical and psychological risks inherent in competitive youth sport and suggest that youth sport scholarship recipients may be at higher risk for injury, competitive anxiety, overtraining, and withdrawal from sport (Gould \& Dieffenbach, 2003; Malina \& Cumming, 2003).

The cost to play rose significantly as young athletes progressed through the competitive soccer system. Athletes indicated they were cognizant of how expensive it was to continue playing competitive soccer and discussed the types of financial sacrifices their families made that enabled them to play at elite levels. 
Many athletes expressed gratitude for the financial sacrifices made by their families that enabled them to play. The longer families committed to support the high costs of playing competitive soccer, the higher the stakes became, and the greater the expectations of a big payoff at the end. These findings illustrate the pressures families and young athletes face as they become financially and emotionally invested in an elite soccer career for one child in the family.

\section{The Injury Culture}

The influence of injury on talent development in sport is not well understood, and limitations exist in the available literature that describes the nature, frequency, and causes of youth sport injuries (Anderson, 2003; Burton et al., 2006; Steffen \& Engebretsen, 2010). Emerging research is beginning to associate injury with early sport specialization, higher volumes and intensities of play, gender, and adolescence (Jayanthi \& Dugas, 2017). In contrast to the literature, accounts of injuries could not be associated exclusively with those who followed an early specialization pathway to Division I. Similar to the findings of Jayanathi and Dugas (2017), the timing of injury occurred during adolescence (ages 11-18) and coincided with the increased volume and intensity of play once athletes moved to competitive soccer. These findings add concern to those previously raised in the literature related to injury in adolescent female populations and indicate that simply playing multiple sports does not protect young athletes from injury during childhood. A further indication suggests that 
injury may be associated with the total volume and intensity of play across all sports during youth and the lack of appropriate rest periods between seasons.

A concerning finding from this investigation was how injury has become an accepted part of the culture of youth sport. Athletes described how they routinely played through injury, hid injury from coaches, and carried injuries forward into their collegiate playing careers. The results of this investigation suggested that reports of injury in competitive youth soccer may be underestimated. Fear of losing their starting spots and fear of missing the recruiting window were two reasons cited for playing with injury. Athletes also experienced additional pressure from themselves, parents, and coaches to keep playing during periods of peak competition such as big tournaments or championship games. Within the literature, Coakley (2009) describes how being willing to risk physical well-being and play with pain are two characteristics of the power and performance model of sport, and evidence of these themes was found. These findings are similar to those of Bejar (2013) and Theberge (2008) in elite adult populations that described how elite adult athletes feel pressured to play through injury and may withhold information from medical staff.

Athletes described how they "felt lucky" to have escaped more serious injury during their youth playing careers. While many athletes experienced multiple significant injuries that kept them out of play for a few weeks to months at a time, they presented their stories of injury as if they were badges of honor or rites of passage for "serious" soccer players. The athletes who participated in this study 
were the lucky ones. They "made it" to Division I soccer. Others were not so lucky. Athletes recounted stories of teammates whose careers ended abruptly because of serious injury (e.g. ACL tear, multiple concussions). These findings suggested that injury is a significant variable that can have a potentially devastating physical and psychological influence on a young athlete's progression within the competitive youth soccer system.

\section{Conclusion}

The early sport experiences shared by 15 elite female athletes contribute to our understanding of how youth develop and progress to elite levels of soccer within the US. A key finding from this research is that whether an athlete specialized early or followed a more diversified pathway through youth sport had little relevance to their eventual progression to Division I soccer. Playing competitive soccer from an early age emerged as the most significant factor that ultimately influenced a young athlete's progression through the youth soccer system.

This investigation provided a window into the world of professionalized youth soccer in the US where athletes spent their earliest years. The results illustrated how competitive youth soccer has become pay-to-play and out of reach for families from lower socio-economic backgrounds. The culture of injury emerged as a significant area of concern as athletes described how they accepted injury, hid injury, played through injury, and carried injury forward into their collegiate playing careers. Finally, and perhaps most importantly, the findings add to the 
growing list of concerns from researchers, parents, coaches, and administrators who have questioned whether highly competitive, organized sport programs are providing a developmentally appropriate environment for youth (Coakley, 2010;

Fraser-Thomas et al., 2005; Gould, 2009; Malina, 2010).

\section{References}

Acosta, R. V., \& Carpenter, L. J. (2014). Woman in Intercollegiate Sport: A Longitudinal, National Study. Thirty-Seven Year Update, 19772014. Acosta-Carpenter.

American Academy of Pediatrics. (2000). Intensive training and sports specialization in young athletes. Pediatrics, 106, 01: 154-157. doi:10.1542/peds.106.1.154. PMID:10878168.

Anderson, S.J. (2003). Injury profiles and surveillance of young athletes. In R.M. Malina \& M.A. Clark (Eds.), Youth sports: Perspectives for a new century. (pp. 94-100). Monterey, CA: Coaches Choice.

Bailey, R., Collins, D., Ford, P., MacNamara, A., Toms, M., \& Pearce, G. (2010). Participant development in sport: An academic review. Sports Coach UK, 4, 1-134.

Baker, J. (2003). Early specialization in youth sport: A requirement for adult expertise? High Ability Studies, 14(1), 85-94.

Baker, J., Cobley, S., \& Fraser-Thomas, J. (2009). What do we know about early sport specialization? Not much! High Ability Studies, 20(1), 77-89.

Baker, J., Côté, J., \& Abernethy, B. B. (2003). Sport-specific practice and the development of expert decision-making in team ball sports. Journal Applied Sport Psychology, 15,12-25.

Baker, J., Côté, J., \& Deakin, J. (2005). Expertise in ultra-endurance triathletes early sport involvement, training structure, and the theory of deliberate practice. Journal of Applied Sport Psychology, 17, 64-78.

Baker, J., \& Horton, S. (2004). A review of primary and secondary influences on sport expertise. High Ability Studies, 15(2), 211-228. 
Baker, J., Horton, S., Robertson-Wilson, J., \& Wall, M. (2003). Nurturing sport expertise: factors influencing the development of elite athlete. Journal of Sports Science and Medicine, 2, 1-9.

Bejar, M. P. (2013). Experiences of coping with injury in Division I athletes from low-to-middle socioeconomic status backgrounds. San Jose State University.

Berg, B.L. (2004). A dramaturgical look at interviewing. In B.L. Berg, Qualitative research methods for the social sciences (pp. 75-122.) Boston: Pearson Education.

Brenner, J. S. (2007). Overuse injuries, overtraining, and burnout in child and adolescent athletes. Pediatrics, 119, 1242-1245.

Doi:10.1542/peds.2007-0887

Bridge, M. W., \& Toms, M. R. (2013). The specializing or sampling debate: a retrospective analysis of adolescent sports participation in the UK. Journal of Sports Sciences, 31, 87-96. doi:10.1080/02640414.2012.72156.

Brustad, R.J. (2003). Parental roles and involvement in youth sport: psychosocial outcomes for children. In R.M. Malina \& M.A. Clark (Eds.), Youth sports: Perspectives for a new century. (pp. 193-212). Monterey, CA: Coaches Choice.

Brylinsky, J. (2010). Practice makes perfect and other curricular myths in the sport specialization debate. Journal of Physical Education, Recreation \& Dance, 81(8), 22-25. Doi:10.1080/07303084.2010.10598522

Burton, L. J., VanHeest, J. L., Rallis, S. F., \& Reis, S. M. (2006). Going for gold: Understanding talent development through the lived experiences of US female Olympians. Journal of Adult Development, 13, 124-136.

Butcher, J., Lindner, K.J., Johns, D.P. (2002). Withdrawal from competitive youth sport: a retrospective ten-year study. Journal of Sport Behavior, 25(2), 145.

Coakley, J. (1992). Burnout among adolescent athletes: A personal failure or social problem. Sociology of Sport Journal, 9, 271-285.

Coakley, J. (2009). Sports in society: Issues and controversies $\left(10^{\text {th }}\right.$ ed). New York: McGraw-Hill. 
Coakley, J. (2010). The "logic" of specialization: Using children for adult purposes. Journal of Physical Education, Recreation \& Dance, 81(8), 16-25.

Colvin, A. C., \& Lynn, A. (2010). Sports-related injuries in the young female athlete. Mount Sinai Journal of Medicine, 77, 307-314.

Doi:10.1002/msj.20179

Côté, J. (1999). The influence of the family in the development of talent in sport. The Sport Psychologist, 13, 395-417.

Côté, J., Baker, J., \& Abernethy, B. (2007). Practice and play in the development of sport expertise. In G. Tenenbaum \& R.C. Eklund (Eds.), Handbook of sport psychology (pp.184-202). New Jersey: John Wiley \& Sons.

Côté, J., Ericsson, K. A., \& Law, M. P. (2005). Tracing the development of athletes using retrospective interview methods: A proposed interview and validation procedure for reported information. Journal of Applied Sport Psychology, 17, 1-19.

Côté, J. and Hay, J. (2002). Children's involvement in sport: A developmental perspective. In J. M. Silva and D. E. Stevens (Ed.), Psychological Foundations of Sport (pp. 484-502) Boston, MA: Allyn \& Bacon.

Côté, J., Lidor, R., \& Hackfort, D. (2009). ISSP position stand: To sample or to specialize? Seven postulates about youth sport activities that lead to continued participation and elite performance. International Journal of Sport and Exercise Psychology, 7, 7-17.

Côté, J., Salmela, J.H., Baria, A., \& Russell, S. J. (1993). Organizing and interpreting unstructured qualitative data. The Sport Psychologist, 7, 127-137.

Dale, G. A. (2000). Distractions and coping strategies of elite decathletes during their most memorable performances. The Sport Psychologist, 14, 17-41.

Denzin, N.K. \& Lincoln, Y.S. (2003). Introduction: The discipline and practice of qualitative research. In Denzin, N.K. \& Lincoln, Y.S. (Eds.), The landscape of qualitative research: Theories and issues, $2^{\text {nd }}$ ed. (pp.1-45). Thousand Oaks, CA: Sage.

DiFiori, J. P. (2010). Evaluation of overuse injuries in children and adolescents. Current Sports Medicine Reports, 9, 372-378.

Doi:10.1249/JSR.0b013e3181fdba58 
DiFiori, J. P., Benjamin, H. J., Brenner, J. S., Gregory, A., Jayanthi, N., Landry, G. L., \& Luke, A. (2014). Overuse injuries and burnout in youth sports: a position statement from the American Medical Society for Sports Medicine. British Journal of Sports Medicine, 48, 287-288.

Eckstein, R (2017). How College Athletics Are Hurting Girls' Sports: The Pay-toPlay Pipeline. Lanham, MD: Rowman \& Littlefield Publishers.

ECNL. (2016). Retrieved December 18, 2016, from http://www.eliteclubsnationalleague.com/about-ecnl/history/

Elliot, D. L., Goldberg, L., \& Kuehl, K. S. (2010). Young women's anterior cruciate ligament injuries. Sports Medicine, 40, 367-376.

Ericsson, K., Krampe, R. T., \& Tesch-Römer, C. (1993). The role of deliberate practice in the acquisition of expert performance. Psychological Review, 100, 363-406. Doi:10.1037/0033-295X.100.3.363

Farrey, T. (2008). Game on: The All-American race to make champions of our children. New York, NY: ESPN Books.

Fawver, B., \& Spengler, J.O., (2014). Funding for youth sport: Learning from the past and aligning resources for the future. Aspen Institute's Project Play: Reimagining Youth Sports in America. https://assets.aspeninstitute.org/content/uploads/files/content/docs/UF_SP ARC_Funding_Youth_Sport_Research_Brief.pdf

Ford, P. R., Ward, P., Hodges, N. J., \& Williams, A. (2009). The role of deliberate practice and play in career progression in sport: The early engagement hypothesis. High Ability Studies, 20(1), 65-75. doi:10.1080/13598130902860721

Fraser-Thomas, J., \& Côté, J. (2006). Youth sports: Implementing findings and moving forward with research. Athletic Insight, 8(3), 12-27.

Fraser-Thomas, J. L., Côté, J., \& Deakin, J. (2005). Youth sport programs: An avenue to foster positive youth development. Physical Education \& Sport Pedagogy, 10, 19-40. Doi:10.1080/1740898042000334890

Fraser-Thomas, J., Côté, J., \& Deakin, J. (2008a). Examining adolescent sport dropout and prolonged engagement from a developmental perspective. Journal of Applied Sport Psychology, 20, 318-333.

Doi:10.1080/10413200802163549 
Fraser-Thomas, J., Côté, J., \& Deakin, J. (2008b). Understanding dropout and prolonged engagement in adolescent competitive sport. Psychology of Sport and Exercise, 9, 645-662.

Gould, D. (2009). The professionalization of youth sports: It's time to act! Clinical Journal of Sport Medicine, 19, 81-82.

Gould, D., \& Carson, S. (2004). Fun \& games?: Myths surrounding the role of youth sports in developing Olympic champions. Youth Studies Australia, 23(1), 19.

Gould, D., \& Dieffenbach, K. (2003). Psychological issues in youth sports: Competitive anxiety, overtraining, and burnout. Youth sports: Perspectives for a new century, 383-402.

Hecimovich, M. (2004). Sport specialization in youth: A literature review. Journal of the American Chiropractic Association, 41(4), 32-41.

Hedstrom, R., \& Gould, D. (2004). Research in youth sports: Critical issues status. White paper summaries of existing literature.

Helsen, W. F., Starkes, J. L., \& Hodges, N. J. (1998). Team sports and the theory of deliberate practice. / Les sports dequipe et la theorie de la pratique choisie. Journal Sport \& Exercise Psychology, 20, 12-34.

Jayanthi, N., Pinkham, C., Dugas, L., Patrick, B., \& LaBella, C. (2013). Sports specialization in young athletes evidence-based recommendations. Sports Health: A Multidisciplinary Approach, 5, 251-257.

Doi:10.1177/1941738112464626

Jayanthi, N. A., \& Dugas, L. R. (2017). The Risks of Sports Specialization in the Adolescent Female Athlete. Strength \& Conditioning Journal, 39(2), 20-26.

Johnson, J. H. (2008). Overuse injuries in young athletes: Cause and prevention. Strength \& Conditioning Journal, 30(2), 27-31.

Kay, T. (2000). Sporting excellence: A family affair? European Physical Education Review, 6, 151-169. Doi:10.1177/1356336X000062004

Law, M. P., Côté, J., \& Ericsson, K. A. (2008). Characteristics of expert development in rhythmic gymnastics: A retrospective study. International Journal Sport and Exercise Psychology, 5, 82-103. 
Leberman, S., \& LaVoi, N. (2011). Juggling balls and roles, working mothercoaches in youth sport: Beyond the dualistic worker-mother identity. Journal of Sport Management, 25, 474-488.

Leite, N., Baker, J., \& Sampaio, J. (2009). Paths to expertise in Portuguese national team athletes. Journal of Sports Science and Medicine, 8, 560566.

Lincoln and Guba's evaluative criteria. (2006) Robert Wood Johnson Foundation. Qualitative Research Guidelines Research Project. Retrieved from http://www.qualres.org

Maffulli, N., Baxter-Jones, A. D. G., \& Grieve, A. (2005). Long term sport involvement and sport injury rate in elite young athletes. Archives of Disease in Childhood, 90, 525-527.

Maffulli, N., \& Bruns, W. (2000). Injuries in young athletes. European Journal of Pediatrics, 159, 59-63.

Malina, R. M. (2010). Early sport specialization: Roots, effectiveness, risks. Current Sports Medicine Reports, 9, 364-371.

Malina, R.M., \& Cumming, S.P. (2003). Current status and issues in youth sports. In R.M. Malina \& M.A. Clark (Eds.), Youth sports: Perspectives for a new century. (pp. 7-25). Monterey, CA: Coaches Choice.

Marshall, C., \& Rossman, G. B. (2006). Chapters 2 \& 3 (Conceptual frameworks and research design). In C. Marshall \& G.B. Rossman, Designing qualitative research, $4^{\text {th }}$ ed., (pp. 23-74). Thousand Oaks, CA: Sage.

Miyata, H., \& Kai, I. (2009). Reconsidering evaluation criteria for scientific adequacy in health care research: an integrative framework of quantitative and qualitative Criteria. International Journal of Qualitative Methods, 8(1), 64-75.

National Association for Sport and Physical Education. (2010). Guidelines for participation in youth sport programs: Specialization versus multi-sport participation [Position statement]. Reston, VA: Coakley, J. Sheridan, M., Howard R., Graham, T., Faigenbaum, T.

National Council of Youth Sports, Report on Trends and Participation in Organized Youth Sports, 2008, retrieved from http://www.ncys.org/publications/2008-sports-participation-study.php 
National Federation of State High School Associations, 2016-17 High School Athletics Participation Survey, 2017, retrieved from http://www.nfhs.org/ParticipationStatistics/PDF/201617_Participation_Survey_Results.pdf

National Physical Activity Plan Alliance. (2014). The 2014 United States Report Card on Physical Activity for Children \& Youth. Retrieved from http://www.physicalactivityplan.org/reportcard/NationalReportCard_longfor m_final\%20for\%20web.pdf

O'Kane, J. W., Spieker, A., Levy, M. R., Neradilek, M., Polissar, N. L., \& Schiff, M. A. (2014). Concussion among female middle-school soccer players. JAMA pediatrics, 168, 258-264.

O'Sullivan, J. (2014). Changing the Game. New York, NY: Morgan James Publishing.

Pennington, B. (2008). Expectations lose to reality of sports scholarships. New York Times. Retrieved from http://www.nytimes.com/2008/03/10/sports /10scholarships.html?pagewanted=all\&_r=0

Sabo, D. and Veliz, P. (2008). Go Out and Play: Youth Sports in America. East Meadow, NY: Women's Sports Foundation.

Sabo, D., \& Veliz, P. (2012). Decade of decline: gender equity in high school sports. Ann Arbor, MI: SHARP Center for Women and Girls.

Sagas, M., \& Cunningham, G. (2014). Sport Participation Rates among Underserved American Youth. Aspen Institute's Project Play: Reimagining Youth Sports in America. http://www. Aspeninstitute.

Org/sites/default/files/content/docs/education/Project_Play_Underserved_ Populations_Roundtable_Research_Brief. PDF.

Silvers, H. J., \& Mandelbaum, B. R. (2007). Prevention of anterior cruciate ligament injury in the female athlete [Special Issue]. British Journal of Sports Medicine, 41, i52-i59.

Soberlak, P, \& Côté, J. (2003). The developmental activities of elite ice hockey players. Journal of Applied Sport Psychology, 15, 41-49.

Sokolove, M. (2008). Warrior girls: Protecting our daughters against the injury epidemic in women's sports. New York, NY: Simon and Schuster. 
Spalding, N. J., \& Phillips, T. (2007). Exploring the use of vignettes: From validity to trustworthiness. Qualitative Health Research, 17, 954-962.

Strachan, L., Côté, J., \& Deakin, J. (2009). "Specializers" versus "samplers" in youth sport: Comparing experiences and outcomes. The Sport Psychologist, 23, 77-92.

Staurowsky, E. J., DeSousa, M. J., Miller, K. E., Sabo, D., Shakib, S., Theberge, N., Veliz, P., Weaver, A., \& Williams, N. (2015). Her Life Depends On It III: Sport, Physical Activity, and the Health and Well-Being of American Girls and Women. East Meadow, NY: Women's Sports Foundation.

Steffen, K., \& Engebretsen, L. (2010). More data needed on injury risk among young elite athletes. British Journal of Sports Medicine, 44, 485-489.

Theberge, N. (2008). "Just a normal bad part of what I do": Elite athletes' accounts of the relationship between health and sport. Sociology of Sport Journal, 25, 206-222.

Weiss, M (2003). Social influences of children's psychosocial development in youth sport. In R.M. Malina \& M.A. Clark (Eds.), Youth sports: Perspectives for a new century. (pp. 109-126). Monterey, CA: Coaches Choice.

White, J., \& Oatman, D. (2009). Does specializing in team sports during childhood translate into a college athletic career. Missouri Journal of Health, Physical Education, Recreation and Dance, 19, 20-24.

Wiersma, L. D. (2000). Risks and benefits of youth sport specialization: Perspectives and recommendations. Pediatric Exercise Science, 12, 13-22.

Yungblut, H. E., Schinke, R. J., \& McGannon, K. R. (2012). Views of adolescent female youth on physical activity during early adolescence. Journal of Sports Science \& Medicine, 11, 39-50. 
Appendix A

Participant Profiles

\begin{tabular}{|l|c|c|c|c|}
\hline Pseudonym & Age & Scholarship & \multicolumn{2}{c|}{ Ethnicity } \\
\hline Addison & 18 & Yes & White/Caucasian & CA \\
\hline Carla & 20 & Yes & White/Caucasian & CA \\
\hline Haley & 20 & Yes & White/Caucasian & CA \\
\hline Dani & 21 & Yes & African & CA \\
\hline Alice & 20 & Yes & White/Caucasian & NV \\
\hline Vicki & 19 & Yes & Asian American & WA \\
\hline Taylor & 19 & No & White/Caucasian & CA \\
\hline Kayla & 18 & Yes & Mexican/Hawaiian/ & CA \\
\hline Nicole & & & Caucasian & \\
\hline Amanda & 19 & No & Mexican American & CA \\
\hline Morgan & 21 & No & White/Caucasian & CA \\
\hline Maya & 18 & Yes & German American & WA \\
\hline Allison & 20 & Yes & Mexican Filipino & CA \\
\hline Sydney & 18 & Yes & White/Caucasian & AZ \\
\hline Jenna & 18 & Yes & White/Caucasian & CA \\
\hline
\end{tabular}




\section{Appendix B}

\section{Semi-Structured Interview Guide}

1. How long have you been playing soccer?

a. Can you describe your earliest vivid memory of an experience with soccer?

b. Was there a specific time or event when you knew soccer was for you?

2. What kinds of youth sport programs did you participate in growing up?

a. What types of team or school sports did you play?

b. What's your favorite memory of a youth sport?

c. What's your least favorite memory of a youth sport?

3. Did you specialize in soccer during childhood or adolescence?

a. How old were you?

b. Can you tell me more about that decision?

c. What were some of the factors that influenced that decision?

4. Describe the pathway you took through sport to reach Division I soccer.

a. How were you first introduced to soccer? How old were you?

b. Describe your soccer progression pathway prior to college. Did your pathway change along the way?

c. Which of these teams, organizations, or schools do you feel played the biggest part in helping you reach your goals in soccer?

5. Tell me about a time when your motivation or desire to play soccer may have changed or evolved.

a. Were there any major life events that had a significant impact on your sport experience prior to college?

b. Was there a person, event, or experience that had a significant impact on your desire to continue playing soccer?

6. Describe the major factors/influences that you feel had the most significant impact on your ability to play soccer at the Division I level.

a. What were the most significant factors that you think led to your development in soccer?

b. Which of these factors do you think had the most influence on your ability to play at Division I?

7. How do you think soccer impacted your overall development during childhood and adolescence?

a. Health \& fitness? Social life? Friends? Family? Teammates? Coaches? Choice of schools? Future career path?

b. How do you think your life may have been different without soccer?

8. Is there anything else you would like to contribute regarding your development in soccer? 
Appendix C

Self-Reflexive Statement

This thesis is the result of many years of personal, professional, and academic achievement. It is a story that began years ago when I first began playing sport. It is the culmination of many years spent on soccer fields as an athlete, a coach, and a parent. My interpretations have been influenced and shaped by so many wonderful, intelligent, and caring individuals. My perspective is multifaceted, and has influenced the way in which I presented this story. It is a story I have been talking about for many years. I am grateful to all the people who have listened, contributed, and enabled me to tell it. I provide a short description of my biases and presuppositions so you can assess the interpretations provided, and form your own conclusions. My hope is that you will find value within these pages and be inspired to make your own contribution to this exciting and meaningful area of research.

As a young, first generation American I grew up playing many sports in the US and Australia. I was introduced to a variety of sports including tennis, swimming, soccer, softball, basketball, volleyball, water skiing, snow skiing, and others during my childhood, primarily through free, unstructured play at home or at school. I grew up with three siblings and a family who taught me the value of hard work and education. We did not have a lot of free time for recreational activities growing up, and I did not play any team sports until I reached middle school, and then played a variety of sports through the school system. I played competitive softball for a short time and then dropped out because I was unable to get to and from practice because both my parents worked, and sports were a significant distance away from my home. As an adult, I have continued recreational participation in different sports for many decades and strongly believe in the power of sport to enable a healthy and active lifestyle.

Over the last 15 years I have watched the transformation of my local community soccer league into a highly competitive, European affiliated, football club. I have had many conversations with athletes, parents, and coaches discussing the issues confronting youth sports today and highlighted through the literature review. I have experienced many of the issues first hand through the youth sport careers of my four children (two girls, two boys), and felt the anguish and heart break expressed by other parents, when the light of sport goes out in the eyes of your child. I am concerned about the increasingly competitive nature of youth sport and what this means for access and participation for all children and young adults.

My passion is female development through sport, and I am concerned about the injury rate for young adolescent female athletes. As a recreational athlete, I too have suffered injury through sport, and continue to be limited 
athletically by the effects of injury suffered earlier in my life. I have personally witnessed serious injury during youth sport competitions, and have seen the devastating effect an injury can have on a young athlete and their families during middle school or high school. The evidence and culture of injury described through these interviews concern me greatly. I believe the risk of injury in youth sport can be managed and mitigated through scientifically based injury prevention programs, and through education and training. Injury prevention programs exist today that will enable young female athletes to compete at elite levels of competition and keep them on the field for as long as they want to play.

I believe every child is an athlete waiting to be developed. Development and participation in sport spans a lifetime, and during childhood and adolescence our focus should be on teaching skills for life long participation and love of sport. I fully believe in access and participation in sport for children from all races, genders, and socioeconomic backgrounds. I know sport has the power to change lives, because it changed mine. Compelling evidence was described in this study that showed the impact sport can have in the lives of young female athletes. It is my hope that this paper will be used by stakeholders and participants to inform and catalyze conversations related to the mission, goals, and objectives of youth sport. We have an opportunity to change the culture of youth sport to better serve all young athletes. I hope we will take it. 


\section{Appendix D \\ Common Pathways}

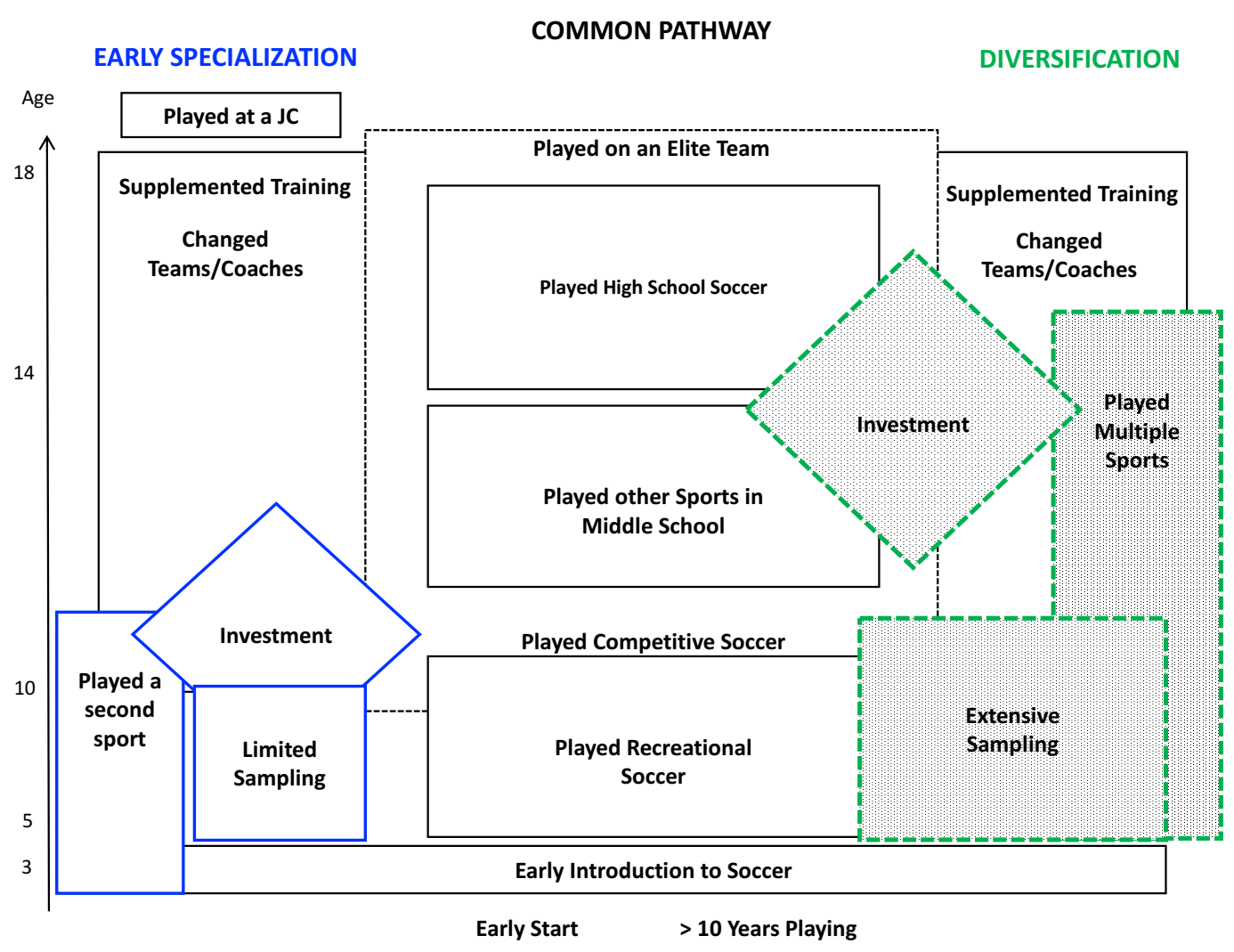




\section{Appendix $\mathrm{E}$}

\section{Composite Vignette Themes and Sub Themes}

\begin{tabular}{|c|c|c|c|}
\hline Timeline & $\begin{array}{l}\text { Vignette } \\
\text { theme }\end{array}$ & $\begin{array}{l}\text { Sub themes } \\
\text { Ava: } \\
\text { Early Specialization }\end{array}$ & $\begin{array}{l}\text { Sub themes } \\
\text { Natalie: } \\
\text { Diversification }\end{array}$ \\
\hline $\begin{array}{l}\text { Early } \\
\text { Development } \\
\text { (Ages 3-9) }\end{array}$ & Early start & $\begin{array}{l}\text { Bonded early with soccer } \\
\text { Limited sampling of other sports }\end{array}$ & $\begin{array}{c}\text { Loved soccer } \\
\text { Sampled many different sports }\end{array}$ \\
\hline \multirow[t]{2}{*}{$\begin{array}{l}\text { Adolescence } \\
\text { (Ages 10-18) }\end{array}$} & $\begin{array}{l}\text { Competitive } \\
\text { Soccer }\end{array}$ & $\begin{array}{c}\text { Specialized early } \\
\text { Played on many teams } \\
\text { Received a youth sport scholarship to play }\end{array}$ & $\begin{array}{l}\text { Multisport athlete } \\
\text { Played for same team } \\
\text { Soccer was expensive }\end{array}$ \\
\hline & Injury & $\begin{array}{l}\text { Played through injury } \\
\text { Hid injury }\end{array}$ & $\begin{array}{c}\text { Accepted injury } \\
\text { Carried injury forward }\end{array}$ \\
\hline
\end{tabular}

